—総 説——

\title{
脂肪の添加給与と乳牛の乳脂肪分泌について
}

田中桂一

岐阜大学農学部, 各務原市 504

\section{Effects of Dietary Fat on Milk Fat Secretion in the Dairy cow}

\author{
Keiichi Tanaka \\ Faculty of Agriculture, Gifu University, \\ Kakamihara-shi 504
}

近年, 牛乳の生産学增加さ也るために，あるいは高能 力牛のエネルギー捸取量を高めるために，飼料中に添加 する油粕類や油脂の量を增加寸る傾向にあるので，飼料 中に油脂を添加すると，生産された牛乳の組成にどのよ うな影響定およぼすかということが興味ある問題として 研究されるようになってきた。また我国においては特乳 の支払い万法が乳脂率によっておこなわれているため， 乳脂率を低下させないで，しかも乳量を増加させるよう な乳牛の飼養管理ということが酪農家にとって重要な間 題である.

飼料中へ脂肪岇添加した際，エネルギー利用というこ とに関しては，相反する結果が報告されているたとえ ば，㐫る研究者は飼料中の脂肪含量が高くなるとケトー ジスがみられ，エネルギー利用に戊效果がなかったとし ている1-3). 一方，飼料效率が良くなり，ケトージスは 観察されなかったという報告すある4-6). しかし，いず れの報告も添加する脂肪の不飽和度乙効䇣之の関係, あ 当いは添加す当脂肪量と效率との関係については述べら れていない.

乳脂肪に関しては，飼料に添加する脂肪が飽和脂肪酸 であるか，不飽和脂肪酸であるがよって，大きな堂が 古くから観察されている。字た最近の10 年閒，この問 题に関して，生化学的な研究も活発になされ，多くの知 見加得られ，報告されている。民れててれらの知見を参 考にして，脂肪給与と乳脂肪分泌について述べてみた w.

日畜会報， $49(2) ： 81-88$ 。

\section{1. 飼料中の脂質の消化と吸収}

放收中の反知䣦物の主要な飼料はイネ科およびマメ科 の牧草類であり，そこに含まれている脂質は主に monoと di-galactoglycerides である.一方，教物類の種子な どの濃厚飼料中の脂質は主に triglycerides として存在 している，またこれらの脂質家構成している脂肪酸は主 に linoleic acid や linolenic acid のような炭素数 180 不飽和脂肪酸である.

第一胃内に送り込まれたこれらの脂質は，そこに生棲 している微生物の lipase によって活発に加水分解学 受 け, さらに遊離された不飽和脂肪酸は第一胃内微生物に より順次水素添加甞受けて，宸素数 18 の不飽和脂肪酸 の多くの異性体や飽和脂肪酸（主に stearic acid）にか えられる，第一贯内における加水分解や水素添加の機序 に関しては DAwSON and KAMP ${ }^{7)}$ 抢よび田中 ${ }^{81}$ によって詳 しく述べられている。第一胃内でなされる水素添加の程

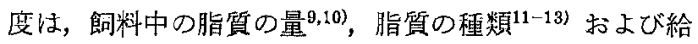
与回数などによって異なる. また給与する粗飼料の種類 や量のような他の要因なども第一昌内微生物の菌相に影 響老与え，そのため不飽和脂肪酸の水素添加の程度に变 化を叔将すことが考えられる。

飼料中の脂質として摄取した脂肪酸以外，第一胃内微 生物によって合成されたり，あるいは第一胃内微生物を 辈成している物質の1つとして取匀込まれた脂肪酸は第 四胃を通り，小腸に送られ，反算動物によって吸收利用 


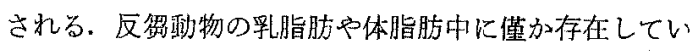
る側鎖脂肪酸や炭素数奇数の脂肪酸などは，この第一胃 内微生物に由来しているものと考えられている.

第一笃内のこれらの作用のため，十二指腸に入ってく る脂肪酸組成は，䝭料中の脂塤の脂肪酸とは相当異って いる，反缺動物において長鎖脂肪酸が小腸放ら吸収され る詳練な機序性明らかにされていないが，单胃動物と同 㬨, lipoproteins である chylomicrons としてリッパ系 に吸収され，胸管りンパ系索通って，项静脈血中に送ら 北ている。

\section{2. 脂肪の添加給与と第一胃内 VFA}

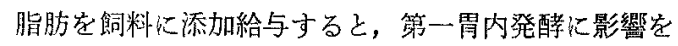
およぼし，次いで乳脂肪生産にも影響をおよぼすことが 知られている。

飼料中に脂肪学添加給与した場合, 第一胃内で生産さ れ尚VFA の比菜におよぼす影響については研究者によ って一椂でない，その原因岋基礎飼料の性質，添加した 脂肪の脂肪酸組成㧍よび添加した脂肪の量上給与方法な どの差によるものであるう ${ }^{14)}$.しかしながら，一般に飼 料中に+フラロー油, 大豆油, 綿実油およびたら肝油な どのような高度不飽和脂肪酸を多量に含有している脂肪 を添加給与すると，第一霄内での発醉に变化をおょぼ $し$, propionic acid と valeric acid のモ儿比增加し, acetic acid, 時には butyric acid のモル比が減少する1526). このことに關して, DEMEY ER and HENDERICKX 277 i土 in vilro の実呀に打いと，第一胃内容液に炭装数 18 の不 饱和脂肪酸を添加与ると, pyruvate と glucose 加年 れぞれ生産される propionic acid とlactic acid が增加 すること在踤告しており，この現象を次の上うに説明し ている.すなわ方，不飽和脂肪酸老第一霄内容液に添加 すると, methane を生産するぐクテリアに直接阻害的に 作用して, methane 道生から propionic acid 産生に水 素利用が変化するためであるうとしている.

\section{3. 脂肪の添加給与とリンパ液および血中の 脂質}

消化器管内での一連の消化を終え, 小腸より吸収され た脂質は小腸リンパ定通り，胸管リンパ系に運ばれる。

この時, 添加給与した脂肪の脂肪酸と同じ脂肪酸がリン 液中に增えるとは限らない，たとえば，牛，筩羊，山

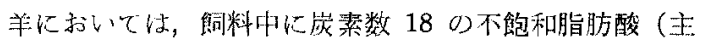
にlinoleic acid, linolenic acid) 多多念有している脂

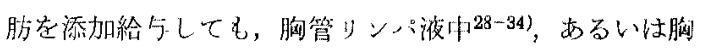

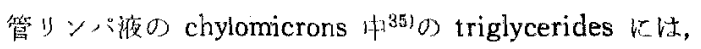

linoleic acid や linolenic acid はごく僅がしか含まれず， これらの脂肪酸は第一胃内において，水素添加を受ける ため, 炭素数 18 の不飽和脂肪酸である stearic acid が 著しく增加する。一方, linoleic acid 多量に含有して いる脂肪党一度に多量に給与したり ${ }^{36)}$ ，第四胃内一直接 注入したり ${ }^{35)}$ ，たサフラワー油をホルムフルデヒドで 処理したカゼインでサフラワー油を保蓝して給与する と ${ }^{37)}$, 刖管リンハ液の chylomicrons 中の triglycerides には著しく linoleic acid 怔增加する. これは, サフラワ 油などに含まれている linoleic acid が第一胃内での微 生物による水素添加を逃れて，小腸方ら吸収されるため である.一方，胸管リンパ液中の phospholipids や cholesterol esters の画分に一般に高い比率で含まれてい る不飽和脂肪酸は胆汁やすい液に存在している脂肪酸が

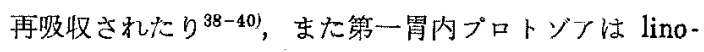
leic acid やlinolenic acid k生合成することが証明され ており41)，これらの脂肪酸が吸収されるためであると考 えられている。

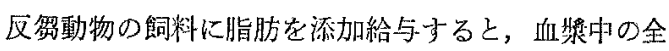
脂質浱度が增加する。そしてこの堌加は主に phospholipids $と$ cholesterol esters の浱度の增加のためであ

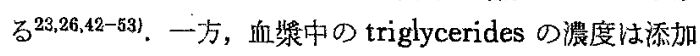
給与する脂肪が， palmitic acid や stearic acid のよう な飽和脂肪酸を多く含有している時, 变化が为られない か，時には增加の傾向宗すが26,47), linoleic acid の上 うな高度不飽和脂肪酸客会している大豆油やサフラワ 一油などを添加給与玨ると，一般に低下するとの報告が 多い23,26,48,53). 脂肪添加䎲よる血脽中の cholesterol esters の增加は，少なくとも肝臓における cholesterolyenesis の增加によるものと考えられている54,55). 一方, サ フラワー油のような高度不飽和脂肪酸を多く含えでいる 脂肪を添加給与すると，血嶈中の triglycerides 濃度が 減少するのは，血流中から triglycerides がすみやがに 消失するか，あるいは肝臓や体脂肪組織における triglyerides の合成または血流中への放出が低下するためで あ万うと思われる．事実，単胃動物や鴊において，高度 不飽和脂肪酸を給与することにより，肝臟や体脂肪組織 における脂質合成能が著しく低下することが報告されて いる56.57)。出た ENGELBERG ${ }^{58}$ は高度不飽和脂肪酸は血垶 中の Low-density Lipoproteins 它加水分解する能力, すな尚ち lipoprotein lipase 活性を增加させ，血洯中の triglycerides の移動在促進寸る効果のあること菠告し ている，反翼動物にサフラロー油を給与した際，高度不 飽和脂肪酸の 1 部は第一胃内での水素添加を逃がれ，小

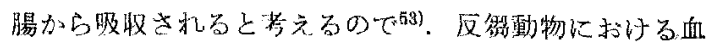


獎中の triglycerides の低下む単胃動物で示されたと同 じ機序によるものかるしれない。

飼料中に添加した脂肪が反微動物の血獎中のいるいる な脂質画分の脂肪酸組成におよぼす影響については多

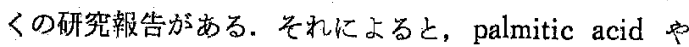
stearic acid を添加給与すると, 血脽中の triglycerides, phospholipids および cholesterol esters のそれらの脂肪 酸は增加与る26,47)。一方, サフラワー油や大豆油のように linoleic acid 多量に含有している脂肪を反华動物に給 与しても，血湘中の triglyceridesには，宸素数 18 で二 重結合を 2 個持っている脂肪酸（以後 $\mathrm{C}_{18}^{\mathrm{a}-}$ 乙する) は懽 がしか存在せず，またそのような脂肪堂添加給与してる 增加は示さず, stearic acid と崖亲数 18 で二重結合を 1 個持っている脂肪酸（以後 $\mathrm{C}_{18}^{1=}$ をする)が增加す $z^{25,26,47,58,53)}$. このこと法添給与した脂肪に含をれて いる linoleic acid などの高度不飽和脂肪酸は第一胃内 で水素添加を受けて， stearic acid や $\mathrm{C}_{18}^{1-}$ と加えられて から吸収されるためである. 血漿中の phospholipids と cholesterol esters 特に cholesterol esters には $C_{18}^{2}-$ が非 常に高い值で存在しており，さらにサフラワー油や大豆 油などを添加給与すると，これらの脂質画分における $\mathrm{C}_{18}^{20}$ の比率は有意心 增加している25,26,41,52,53)。 これは第 一胃内における不飽和脂肪酸への水素添加は飽和脂肪酸 にまで完全になされているのではなく，特に添加した脂 肪の量の多い㭙には，加怡りの linoleic acid が第一资内 での水素添加定逃れて，血流中に移行している ${ }^{53)}$. 4 牛の血 獎中の cholesterol linoleate の生成は小腸加ら吸收され てくる脂肪酸の影響を受けないとする LEAT and $\mathrm{HALL}^{30)}$ の報告もあるが，水素添加を受けずに吸収された linoleic acid 1 lecithin-cholesterol-acyl-transferase system ${ }^{59.60)}$ を通って, phospholipids や cholesterol esters $k$ 取り込まれるのであろう。また MOORE et al. ${ }^{\text {(1) }}$ は西麻仁 油, トウモロコシ油あるいは linoleic lacidを第一胃内 を通さないで，第四骨内に直接注入乙，血獎中の各脂質 画分の脂肪酸組成を経時的に観察した結果，これらの脂 質汇多量化含世れている linoleic acid やlinolenic acid は triglyceridesにおいては，短時間で增加するが， phospholipids では8時間以後, cholesterol estersでは 24 時間以後になって増加している.このことからも，血 漿中の riglycerides $の$ 脂眆酸組成は小腸から吸収された 脂肪酸の影響を直接受けるが, phospholipids や cholesrol esters proteins として，胸管リシパ系を通って四收された後， 肝蔵に運ばれて，そこで加水分解を受けた脂肪酸を取り 込むのであらう。

\section{4. 脂肪の添加給与と乳脂肪分泌}

泌乳中の乳牛に linoleic acid や linolenic acid に含有している植物油（たとえば落花生油あるいは归麻 仁油）定添加した飼料学給与寸ると，乳脂肪中の沃度価 およびヶン化当量加增加し，一方ライヘルトマイ七ル

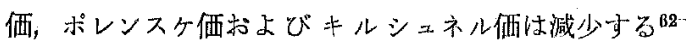
68). HILditch and ThOMPSON 65 ) 持よび HiLditch and JASPERSON ${ }^{68)}$ は乳脂肪の沃度倾が高くなるのは, oleic acid 含量が增加し，炭紫数 4 から 1.4 までの飽和脂肪酸含量 が減少するためであることを示した．とのような古典的 な分析方法によって得られた結果は，近年著しく発達し た gas-liquid chromatography によって, 乳脂肪中の脂 肪酸組成が容易に測定することができるようになり，確 認されてきた，それで乳牛への脂肪の給与多，乳脂肪中 の各々の脂肪酸におよぼす影響を議論する際, 乳脂肪中

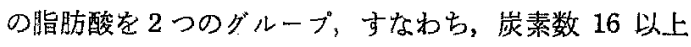
の脂肪酸と，炭素数 4 から 16 までの脂肪酸に分けて述 ベることにする。

展鎖脂肪酸（炭素数 16 以上)：乳牛の飼料比 linoleic acid やlinolenic acid の上うな高度不飽和脂肪酸を 多量に含有している植物油(たとえば, サフラワー油，再 糜仁油, トゥモロコシ油あるいは綿実油など)を添加し， 給与すると, 生産乳量には变化がみられないが, 釈脂肪 生産は減少する。そしてこの時, 乎脂肪中の炭素数 4 か ら 16 までの脂肪酸の尘産量は減少し, stearic acid と $\mathrm{C}_{18}^{-1}$ の生産量は增加す万。し汃し $\mathrm{C}_{18}^{2-}$ や $\mathrm{C}_{1 \mathrm{~B}}^{3-}$ の生库量 は兽加しない、19-22,24-26,32,34,44,69,70). 釈牛の一般的な飼料 中に linoleic acid や linolenic acid が相当高い值で含有 しているにすかかわらず7゙，乳脂肪中にはこれらの脂肪 酸の比澹はきわめて低い，乳脂肪中にこれら不飽和脂肪 酸の含量が低く，またこのような脂肪酸を摄取しても， 增加しないのは，給与された脂肪は，前述の上うに，第 一霄内微生物の作用によって，加水分解を受けた後，遊 離された不飽和脂肪酸は完全に飽和脂肪酸にまで，西る い恃中間物質である $\mathrm{C}_{18}^{1}$ によで水素添加をうけるであ ろう。事実，不飽和脂肪酸第一胃定通さないで，静脈 血流中に直接注入すると，乳脂肪中のこれらの脂肪酸の 比率が高くなる

linoleic acidを多量に含有している㥀物油を添加給与 すると，乳脂肪中の $\mathrm{C}_{18}^{1-}$ の含量が著しく增加するのは， 次の 2 つの機序によるものと考えられる.すなわも，1 つ㥀物油に多量に含安れている linoleic acid は第一。 留内微生物によって，完全に水絜添加が沶こなおれ， stearic acid となって, 血流中の triglycerides に移行 
し，艺れから乳腺内に取り込をれた後，乳腺内に存在し ている desaturase Kょって不䳌和化を受けて， C か无られる76,77)、いま 1 つの機序証第一胃内に打いて, linoleic acid への水蒵添加が不完全であるため, 中間物 質である $\mathrm{C}_{18}^{1=}$ の型で血流中に移行，气れが乳腺内に取 り込ま机，乳脂肪合成に利用されるというものである。 事実, linoleic acid 芯多量に含有している植物油定給与 寸ると, linoleic acid 加第一䏴内微生物によって水絜添 加を受ける際，生成される中間物質であるとされている trans-型 $\mathrm{C}_{18}^{1=}$ が乳脂肪中に增加した全 $\mathrm{C}_{18}^{1}$ の $30 \%$ 以上 を占めている ${ }^{8,20,78,79)}$.

stearic acid を飼料中に添加給与すると，生産乳量に は変化はみられないが，乳脂肪生産は增加し，そしてこ の㭙, 炭素数 4 から 16 までの脂肪酸の生産量牥隇少し, stearic acid と $C_{18}^{1=}$ のそ忙著しく増加している22,26,80). stearic acid 家給与主ると, 乳脂肪中の stearic acid 生産量が增加するのは，血流から乳腺内への stearic acid の取り这文增加ずるためであるう。またこの時, $C_{18}^{1-}$ の生産量が增加するのは, stearic acid が血流中か ら乳腺内に取り込委れた後，その1 部は乳腺内で desa-

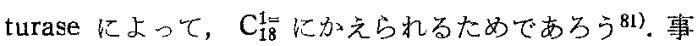
実, この時, 增加する $\mathrm{C}_{1 \mathrm{~B}}^{1 B}$ は, linoleic acid 添加給与 した時, 堌加或る $\mathrm{C}_{18}^{1=}$ の 30\%以上が trans-型のもので あるのに対して，ほとえどが cis-型の $\mathrm{C}_{1 \mathrm{~B}}^{\mathrm{L}}$ 、すなわち oleic acid である.

短鎖およで中鎖脂肪酸 (炭素数 4-16)：脂肪の添加 給与办乳脂肪中の中鎖の脂肪酸（炭素数 12 から 16)の 生産におよぼす影響は様々である。その理由は，これら の脂肪酸は acetate と $\beta$-hydroxybutyrate から乳腺内で 新しく合成されたものと，血嶈中の triglycerides の中鎖 脂肪酸から乳腺内に取り込まれたものとがあるからであ る.たとえば飼料に lauric acid や myristic acid を多 く含有しているヤシ油やパーム核油あるい游離の lauric acid myristic acid を添加して乳牛に給与する そ,乳脂肪中のこれらの脂肪酸の生産量が增加するのは， 血漿中の triglycerides の lauric acid と myristic acid 肪增加し，これらが乳腺内に取り込まれ，乳脂肪合成に 利用されるためである22,25,44,62,63,68,82,83)。しかしながら， palmitic acid では，給与した飼料中にその含量が高い 加ら々って，その時，分泌された乳脂肪中の palmitic acidの生産量は必ずしも增加するとはかきらない，特に は，飼料中の palmitic acid の量が增加しているにもか かからず，乳脂肪中の palmitic acid の生産量は減少さ えしている18,41)。一方, STEELE and MOORE ${ }^{22)}$ 打よび

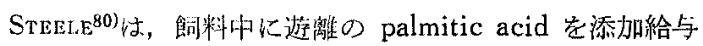

すると，乳脂脏中の capric acid, lauric acid, myristic acid, stearic acid および oleic acid の生産量は隇少す るが， palmitic acid のそれは著しく增加すると報皆し ている、乳脂脄の生産量はいずれの㪕告においてむ，增 加安示している. 乳脂肪中の palmitic acid の生座量 に，このような違いがあるのは，飼料服に脂肪学添加す ると，乳腺内でのpalmitic acid の合成汃減少与ると 之関係多あるのであるう。少なる占, palmitic acidの正 味の生産毦乳腺内で合成される量と, 血流中の triglycerides 加ら乳腺内比取り还生机，乳脂肪合成に利用さ れる palmitic acid の量によって左右されるであろう.

飼料江長鎖の飽和脂肪酸定多量汇含有している脂肪 や，遊離の長鎖の飽和脂肪酸を添加し，乳牛に給与一京る 々，炭素数 4 が 16 までの脂肪酸の生産量が減少する ことが推察されている 由を明確に説明することは困難である. 反筯動物の乳脂 肪の脂肪酸は主に次の 2 つ代謝経路によって合成され ていると考えられている. 1 つ任, acetate と $\beta$-hydroxybutyrate 血流中から乳腺内取り込み，そこで炭素 数 4 から 16 までの脂肪酸を新しく合成する. そしてこ れらの栺肪酸は乳腺内で malonyl-CoA 経路安通り，さ らに 2-glycerophosphate, phosphatidic acid および $\alpha$, $\beta$-diglycerides などの师間代謝物を経て, triglyceride, に取り込まれる76,77.84)。いま 1 つは， chylomicrons 扰よ び Low-density Lipotroteins として血流中に存在してい る triglycerides が乳腚内に取り込まれ，そこで部分的 にまたは完全に加水分解を受けて, 脂肪酸の部分は新し く合成される triglycerides に組み入れられるという経 路である76,85.86). それ故 acetate や $\alpha \beta$-hydroxybutyrate の乳腺内への補給が減少すると，乳脂肪中の短鎖怙よび 中鎖の脂肪酸の生成が減少すること苦劣られる，それ でサフラワー油や大豆油の上うな高度不飽和脂肪酸定多 量に含有している植物油を乳牛に給与した際，第一胃内 容液中の acetic acid 㣽減少することによって, 乳脂肪 中の炭素数 4 から 16 までの脂肪酸が減少したことの 1 部は説明することができる。しかしながらタ口ーゃ stearic acid 給与した際，第一胃内容液中の VFA モ 儿濃度には变化がみられなかったことから，乳脂肪㗅の 炭素数 4 から 16 安での脂肪酸の減少は第一胃内微生物 によって生産される acetic acid や butyric acid の減少 のためだけでは説明できない.MOORE and STEELE ${ }^{877}$ は血 流中の triglycerides 加ら長鎖脂肪酸の乳腺内一の取り 込み分增加すると，乳腙内の辰鎖脂肪酸または longchain fatty acyl-CoA derivatives の濃度が增加すること

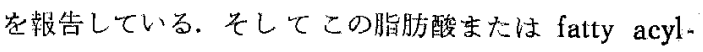




\section{脂肪給与、乳脂肪分泌}

$\mathrm{CoA}$ derivatives の濃度が增加すると acetyl-CoA carboxylase の活性を阻害する ${ }^{88-901}$.そしてての acetyl-CoA carboxylase は乳牛の乳腺内において脂肪酸合成を螌媒 している911. それ故，血流中の triglycerides から stearic acid な゙の乳腺内への取り込多量が增加すると，乳腺 内において, acetate 加ら malonyl-CoA 経路によって合

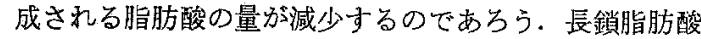
が乳腺内で acetate から合成される脂肪酸の分㹸に抒よ ぼす詳細な研究は KUMAR et al. ${ }^{92}$ によってなされている. 彼らはウサギの乳腺の上清画分を培稌した時, acetate, acetoacetate, butyrate また,$\beta$-hydroxybutyrate 基 質として用いると， avidin は炭素数 6 から 16 までの脂 肪酸の合成を著しく阻害したが, acetate, acetoacetate たは $\beta$-hydroxybutyrate 基質として用いた時，avidin は butyrateの合成にはほとえど影響を叔よぼさなかった ことを報告した。毛れ故，ウサギの乳腺では，acetate か 5 butyrate $の$ 合成には acetyl-CoA $の$ carboxylation 関係なく，別の経路によって合成されることも考えられ る. 乳牛の乳腺においても同様の機序が存在しているな ら，長鎖脂肪酸または fatty acyl-CoA derivatives の濃 度が增加して acetyl-CoA carboxylase の活性が阻害され ても, acetate から butyrate の合成は阻害されないこと 屯考机られる。

\section{5. 血漿中脂質と乳脂肪分泌}

血獎中の各脂質濃度と乳脂肪生应量堂比較ずると，乳 脂肪生産㹥血踏中の cholesterol そその esters, phos- pholipids, unesterified fatty acids および全脂質濃度と の間には関連が認められていないが23,26,48,53,93)，血漿中 のtriglycerides 濃度との間には正の相関が観察されてい $z^{23.26 .53)}$. しかしし MOORE et al. ${ }^{477}$ 注乳脂肪の生産之相関の あるのは，衂中の triglyceridesではなくて，unesterified fatty acidsであると報告している。し办し彼らの実 験は血漿サンプルを腹皮下静脈から採取したむので，こ

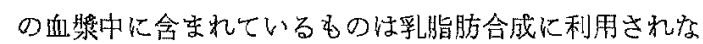
かったため，乳腺内に取り込をれなかったと考えられる 脂質である. 田中らら年のおこなった実験においても，腹 皮下静脈血中の triglycerides 濃度は頸静脈血中のそ和 に比べて, 飼料への脂肪添加の影響は少なく，そして秏 脂肪生産上の関連は認的られなかった．このことは血流 中の triglycerides の濃度が高くなると，乳腺内に取り 迅をれる triglycerides の量が增加するため, 腹皮下静脈 血中の triglycerides 浱度は脂肪の添加給与によって影 響を受けないものと思われる. BARRY et al.85)や ANNISON et $a l_{.}{ }^{76)}$ 注泌乳中の乳牛によって生産される乳脂肪の一部 は chylomicrons および Low-density Lipoproteins $(\alpha<$ 1.019）として血流中に存在している triglycerides に由 米していること示し，さらに WEsT et al. ${ }^{94)}$ や Bishop

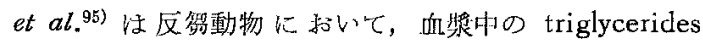
性完に加水分解受け名こと示し，乳脂肪合成已血流 中のtriglycerides との間には直接関係のあることを示し 七尚.

乳腺組織内には stearic acid タ句酳素系汃存在していることが報告されている76,77).

Table 1. Comparison of the ratios of certain fatty acids in the triglycerides in Very Low-Density (VLDL) and Low-Density Lipoproteins (LDL) in serum and milk fat of the cow on each dietary treatment.

\begin{tabular}{|c|c|c|c|}
\hline \multirow{2}{*}{ Ratio } & \multirow{2}{*}{$\begin{array}{l}\text { Unsupple- } \\
\text { mented } \\
\text { ration }\end{array}$} & \multicolumn{2}{|c|}{$\begin{array}{l}\text { Ration containing } \\
\text { safflower oil }\end{array}$} \\
\hline & & $300 \mathrm{~g}$ & $600 \mathrm{~g}$ \\
\hline \multicolumn{4}{|l|}{$\mathrm{C}_{16} / \mathrm{C}_{16}^{1-}$} \\
\hline Milk fat & 22.9 & 19.4 & 16.8 \\
\hline $\begin{array}{l}\text { Triglycerides } \\
\text { in VLDL }\end{array}$ & 12.5 & 11.9 & 9.5 \\
\hline $\begin{array}{l}\text { Triglycerides } \\
\text { in LDL }\end{array}$ & 7.0 & 6.9 & 0.07 \\
\hline \multicolumn{4}{|l|}{$\mathrm{C}_{18} / \mathrm{C}_{18}^{1-1}$} \\
\hline Milk fat & 0.5 & 0.5 & 0.5 \\
\hline $\begin{array}{l}\text { Triglycerides } \\
\text { in VLDL }\end{array}$ & 3.8 & 2.4 & 2.0 \\
\hline $\begin{array}{l}\text { Triglycerides } \\
\text { in LDL }\end{array}$ & 1.4 & 1.4 & 1.4 \\
\hline
\end{tabular}

From Tanaka et al. ${ }^{63)}$ 


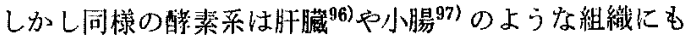
存在していることが知放れている。元れ故, stearic acid を肝臓や小腸においても oleic acid に変換させて乳脂肪 州に分泌することも考岳られる。田中ら ${ }^{531}$ は䎵乳中の乳 牛の飼料にサフラワー油を 1 日 1 頭当り $300 \mathrm{~g}$ あるい は $600 \mathrm{~g}$ 添加給与した実䮖に打いて，血清中のVery Low-density および Low-density Lipoproteins の triglycerides $の$ stearic acid $\left(\mathrm{C}_{18}\right) /$ oleic acid $\left(\mathrm{C}_{1 \mathrm{~B}}^{\mathrm{l}}\right)$ は, 乳脂肪中の $\mathrm{C}_{18} / \mathrm{C}_{18}^{1=}$ に比べて著しく大きく(表に示す) また，るし肝臟や小腸において， stearic acid から oleic acid への变換が活発に起っているならば，乳牛に stearic acid 在給与した実験において ${ }^{26,47)}$ ，血洯中の triglyceri des の oleic acid が增加を示すことが考えられるが，む しろ減少の傾向にある。このことからも，乳牛に stearic acid を給与すると, 乳脂肪中の oleic acidの生産量が增 加するのは2644)，主に血流中の triglycerides から stearic acid を乳腺内に取り込を量范增加し，乳腺内て stearic acid oleic acid に変換するためであるうと考 えられる。一方，乳脂肪中の palmitic acid $\left(\mathrm{C}_{16}\right) / \mathrm{pal}$ mitoleic acid $\left(\mathrm{C}_{16}^{1-}\right)$ は，血清中の Very Low-density お よび Low-density Lipoproteins の triglycerides のそれ に比べて，著しく大きかった(表に示す)。このことは乳 腺太に存在している desaturase 蛙 stearic acid に特異 的に作用し，palmitic acid には特異性が小さいようで ある。

linoleic acid を多舅に含有している大豆油あるいはサ フラワー油を乳牛の飼料に添加給与すると，血槳中の linoleic acid の濃度は著しく增加しており，そしてこの 增加恃主に cholesterol esters と phospholipids の画分 においてである ${ }^{48,531}$.このことは，哴料として提取した linoleic acid の1部は第一胃内での水素添加を逃がれ， 小腸から吸収され，血流中の cholesterol esters および phospholipids の租分に避択的に組み込まれ，triglyceri－ des には僅かしか組み込をれないことを示している。

釈牛の乳脂肪中に必須脂肪酸の含量方少ない理由とし $て$ ，給与された linoleic acid は第一留内微生物によ。 て，活発に水素添加を受けるためであること忟すでによ く知られているが，第一胃内で水素添加学逃がれた linoleic acid は貥脂肪合成には直揬利用されない血流中

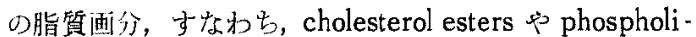
pids の画分に選执的に取り込まれるためと，また血流 中の全 triglycerides の linoleic acid の比率に比べ Very Low-densing および Low-Density Lipoproteins 中の triglycerides の linoleic acid の比摔は低いことか $ら^{53)}$, triglycerides での linoleic acid の分布はかたよ。 たものであり，乳腺によってあまり取り込まれない High-density Lipoproteins に多く分仍しているた好と
考えられる・

\section{Protected fats $の$ 添加給与と乳脂肪分泌}

泌乳初期の牛，あるいは高能力牛に対して十分に满す だけのエネルギーを給与することは非常に困難なことで ある.たとえば，多量の脂肪を飼料に添加して，エネル ギーを增加させようとすると, 消化率, さらに食欲さえ も低下するととが報告されている98). 最近になって， 脂肪をホルムアルデヒドで処理した蛋白質 (formaldehyde-treated protein) の層で保蓝する技術が開発され ている99)、いタらるこの“protected fats”は第一胃内で の微生物による影響を受けることなく，小腸で消化さ れ，そして吸收される 100-102)。そそのため，かなりの量 の protected fats を飼料中に添加してる，消化や食欲な どにはあまり影響を与えないむのと思すれ，それでェネ ルギー撜取量を増加させるため, この protected fats 飼料中に添加し，高能力牛のエネルギー摄取を改善でき る可能性が持たれている. 事实, STORRY et al. ${ }^{1033}$ および MACLEOD et $a l . .^{104)}$ (裖厚飼料多給に上る著しい乳脂肪生 産の低下を, protected tallow を添加給与することによ って，改善できたとしている. さらにサフラワー油のよ うな高度不館和脂肪酸岩多量に含有している脂肪を protect したものを添加給与することによって，乳脂肪 生産を低下させることなく，乳脂肪中の不跑和脂肪酸の 比㨇を增加させることが報告されている102,105-110)。し名 し，この protected fats を乳牛の飼料に添加して給与さ せることに関寸る研究は，始められたばかりであり，問 道点もいくつか残っており，今後の研究が待たれる.

\section{ま と め}

以上，饲料に脂肪を添加し，乳牛に給与した際，生産 される釈脂肪中の脂肪酸組成に打よぼす影響，また血漿 中脂質と乳涽肪分泌之の関係について述べた. 最後に述 ベた protected fats の飼料への添加利用に関する研究は 始められたばかりであり，今後の成果が期待される。ま た反㽞動物に招ける脂質代謝に関する最近の研究は目党 ましいむのがあり，飼料中への脂肪の添加に関する問 題，さらに低脂肪乳に関する問題なども，反算動物の脂 質代謝を通して検剖してゆかなくてはならないであらう と思われる。

\section{文献}

1) MaY:s, P. A., Biochem. J., 71: 459. 1959.

2) Pawan, G. L. S., Proc. Nutr. Soc., 18: 155. 1959.

3) Kuanade, J. M. and M. C. Nath, Proc. Soc. Exp. Biol. Med., 105: 566. 1960.

4) Swift, R.W., W. H. Bratzler, W. H. James, A. D. Tillman and D.C. Meek, J. Anim. Sci., 
27: 539. 1944.

5) Kuryvial, M. S., J. P. Bowland and R. T. Berg, Can. J. Anim. Sci., 42: 23, 1962.

6) Patterson, D.S.P., Res. Vet. Sci., 4: 230. 1963.

7) Dawson, R. M. C. and P. KEMP, Physiology of Digestion and Metabolism in the Ruminant. ed. A. T. Phillipson, 504-518. Oriel Press. Newcastle upon Tyne. 1970.

8）因中桂一，日畜会報，45：307。1974。

9) Czerkawski, J. W., Br. J. Nutr., 21：865. 1967.

10）田中桂一・清水良三・林 英夫，日畜会袁，44： 143. 1973.

11) Noble, R. C., W. Steele and J.H. Moore, Br. J. Nutr., 23: 709. 1969.

12) Moore, J.H., R.C. Noble, W. Steele and J. W. Czerkawski, Br. J. Nutr., 23: 869. 1969.

13）田中桂一・清水良三・林 英夫, 日畜会笮, 44: 212. 1973.

14) Dronovat, N.S., R. W. Stanlex, E. Cobb and K. Morita, J. Dairy Sci., 49: 28. 1966.

15) Shaw, J.C. and W. L. Ensor, J. Dairy Sci., 42: 1238. 1959.

16) Brown, W. H., J.W. Stull and G. H. Stotт, J. Dairy Sci, 45: 191. 1962.

17) Nottle, M.C. and J.A.F. Rook, Proc. Nutr. Soc., 22: vii. 1963.

18) Nicholson, J. W. G., H. M. Cunningham and D. W. Friend, Can. J. Anim. Sci., 43: 309. 1963.

19) Steele, W. and J. H. Moore, J. Dairy Res., 35: 223. 1968.

20) Steel, W. and J. H. Moore, J. Dairy Res., 35: 343. 1968.

21) Steele, W. and J. H. Moore, J. Dairy Res., 35: 353. 1968.

22) Steele, W. and J. H. Moore, J. Dairy Res., 35: 361. 1968.

23) Varman, P. N., L. H. Schultz and R.E. NiChols, J. Dairy Sci., 51: 1956. 1968.

24) Noble, R. Ci, W. Steele and J. H. Moore, J. Dairy. Res., 36: 375. 1969.

25）日中柱一，日畜会倒，41：254. 1970.

26) Tanaka, K., I. Nakajima and H. Hayashi, Jap. J. Zootech. Sci., 44: 165. 1973.

27) Demeyer, D. I. and H. K. Henderickx, Biochim. Biophys. Acta, 137: 484. 1967.

28) Felinski, L., G. A. Garton, A. K. Lough and A. T. Phillipson, Biochim. J., 90: 154. 1964.

29) Heath, T. J., E. P. Adams and B. Morris, Biochem. J., 92: 511. 1964.

30) Leat, W. M. F. and J. G. Hall, J. Agri. Sci, Camb. 71: 189. 1968.

31) Wadsworth, J. C., J. Dairy, Sci., 51;876. 1968.

32) Perry, F. G. and G. K. MacLeod, J. Dairy Sci., 51: 1233. 1968.

33) Bath, I. H. and K. J. Hill, J. Agri. Sci., Camb.
68: 139. 1967.

34) Tanaka, K, I. Nakajima, H. Ito and H. Hayashi, Res. Bull. Fac. Agric. GifuUniv., 33: 295. 1972.

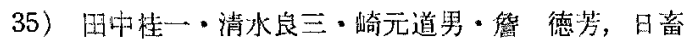
会報, 45：206. 1974：

36) Wadsworth, J. C., J. Dairy Sci., 51: 1382. 1968.

37) Scotr, T.W. and L. J. Cook, Digestion and Metabolism in the Ruminant. ed. I. W. MCDonALD and A.C.I. WARNER, 510-523. The University of New England Publishing Unit. Armidcle. Australia. 1975.

38) Lennox, A. M., A. K. Lough and G. A. Garton, Br. J. Nutr., 22: 237. 1968.

39) Lennox, A. M. and G. A. Garton, Br. J. Nutr., 22: 247.1968.

40) Leat, W.M.F. and F. A. Harrison, Q. J. Exp. Physiol., 54: 187. 1969.

41) Viviani, R. and A. R. Borgatti, Atti, 14th. Conger. Naz. Microbiol, 2: 89. Di Blasio. Napol. Italy. 1967.

42) Bohman, V.R., M. A. Wade and C. Torell, J. Anim. Sci., 21: 241. 1962.

43) Bohman, V. R. and A. L. Lesperance, J. Anim. Sci., 21: 658, 1962.

44) Storry, J. E., J. A. F. Rook and A. J. Hall, Br. J. Nutr., 21: 425. 1967.

45) O'Kelly, J. C., Aust. J. Biol. Sci., 21: 1025. 1968.

46) O'Kelly, J.C. and D. W. Robinson, Aust. J. Agric. Res., 19: 657. 1968

47) Moore, J.H., W. Steele and R. C. Noble, J. Dairy Res., 36: 383. 1969.

48) Steele, W., R. C. Noble and J.H. Moore, J. Dairy Res., 38: 57.1971.

49) Rindsic, R. B. and L. H. Schultz, J. Dairy Sci., 57: 1037. 1971.

50）日中㤬一地皂岩男 - 林 英犬，日蓄会報，44： 165. 1973.

51) Brumby, P. E., J.E. Storry and J. D. Sutton, J. Dairy Res., 39: 168. 1972.

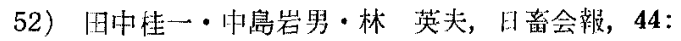
19. 1973.

53）田中桂一一中島岩男・崎元道男 - 林 尖头，岐阜 大農研報，34：373．1973。

54) Linazasoro, J. M., R. Hill, F. Chevaller and I. L. Chajkoff, J. Exp. Med., 107:813. 1958.

55) Mukher jee, S. and R. B. Alfin Slater, Arch. Biochem. Biophys., 73: 359. 1958.

56) Bartley, J.C. and S. Abraham, Biochim. Biophys. Acta, 280: 258. 1972.

57) Romsos, D. R., S. M. Ruiz and G. A. Leveille, Comp. Biochem. Physiol, 53: 19. 1976.

58) Engelberg, H., Metabolism, 15: 796. 1966. 
59) Glomset, J. A., J. Lipid Res., 9: 155.1968.

60) Leat, W. M. F. and J. Baker, Comp. Biochem. Physiol., 36: 153. 1970.

61) Moore, J.H., R. C. Noble and W. Steele, Br. J. Nutr., 23: 141. 1969.

62) Holland, E. B. and J. P. Buckley, J. Agri. Res., 12: 719. 1918.

63) Holland, E. B. and J. P. Buckley, J. Agri. Res., 24: 365, 1923.

64 Sutton, T. S., J. B. Brown and E. W. Johnston, J. Dairy Sci., 15: 209. 1932.

65) Hilditich, T. P. and H. M. Thompson, Biochem. J., 30: 677. 1936.

66) Hill, O. J. and L. S. Palmer, J. Dairy Sci,, 21: 529. 1938.

67) Williams, N.K., C. Y. Canon and D. Espe, J. Dairy Sci., 22: 442. 1939.

68) Hilditich, T.P. and H. Jasperson, Biochem. J., 37: 238. 1943.

69) Storry, J. E., A. J. Hall and V. W. Johnson, Br. J. Nutr., 22: 609. 1968.

70) MacLeod, G. K., A.S. Wood and Y.T. Yao, J. Dairy Sci., 55: 446. 1972.

71) Hilditich, T.P., The Chemical Constituents of Natural Fats. 3rd ed. 95-100. Chapman and Hill Ltd. London. 1956.

72) Tove, S. B. and R. D. Mochrie, J. Dairy Sci., 46: 686.1963.

73) Storry, J. E. and J. A. F. Rook, Biochem. J., 91: 2'/c. 1964.

74) Storry, J.E. and J.A.F. Rook, Biochem. J., 97: 879. 1965.

75) Storry, J. E., A. J. Hall, B. Tuckley and D. Millard, Cr. J. Nptr., 23： 173. 1969.

76) Annison, E. F., J. L. Linzell, S. Fazakerley and B. W. Nichols, Biochem. J., 102: 637 . 1967.

77) Linzell, J. L., E. F. Annison, S. Fazakerley and R. A. LenG, Biochem. J., 104: 34. 1967.

78) WARD, P.F. V., T.W. Scott and R. M. C. DAWSON, Biochem. J., 92: 60. 1964.

79) Tanaka, K. and K. Shigeno, Jap. J. Zootech. Sci., 47: 50, 1976.

80) Steele, W., J. Dairy. Res., 36: 369. 1969.

81) Bickerstaffe, R. and E. F. Annison, Biochem. J., 108: 47P. 1968.

82) Hilditich, T.P. and J. J. Sleightholme, Biochem. J., 24: 1098. 1930.

83) Монамmed, K, W. H. Brown, P. W. Riley and J. W. Stull, J. Dairy Sci., 47: 1208. 1964.

84) Ganguly, J., Biochim. Biophys. Acta, 40: 110. 1960.

85) Barry, J. M., W. Bartley, J. L. Linzell and D. S. Robinson, Biochem. J., 89: 6. 1963.

86) Patton, S. and R. D. McCarthy, J. Dairy Sci.
46: 916. 1963.

87) Moore, J.H. and W. Steele, Proc. Nutr. Soc., 27: 66. 1968.

88) Hiввтt, K. G., Biochim. Biophys. Acta, 116: 56. 1966.

89) Howanitz, P. J. and H. R. Levy, Biochim. Biophys. Acta, 106: 430. 1965.

90) Smith, S. and R. Dils, Biochim. Biophys. Acta, 125: 435. 1966.

91) Ganguly, J., Biochim. Biophys. Acta, 40: 110. 1960.

92) Kumar, S., V. N. Zingl and R. Keren-Paz, Biochim. Biophys. Acta, 98: 221. 1965.

93) Rindsig, R. B. and L. H. Schultz, J. Dairy Sci., 57: 1459. 1974.

94) West, C. E., E.F. Annison and J.L. Linzell, Biochem. J., 104: 59P. 1967.

95) Bishop, C., T. Davies, R. C. Glascock and V. A. Welch, Biochem. J., 113: 629. 1969.

96) Raju, P.K. and R. Reiser, J. Biol, Chem., 242 379. 1967.

97) Bickerstaffe, R, and E. F. Annison, Biochem. J., 107: 27P. 1968.

98) Storry, J. E., P. E. Brumby and G. C. Cheesman, Agri. Dev. Adv. Ser. Q Rev., 15: 96. 1974.

99) Bitman, J., L. P. Dryden, H. K. Goering, R. A. Yoncoskie and L. F. Edmondson, J. Am. Oil. Chem. Soc., 50: 93. 1937.

100) Scott, T. W., L. J. Cook and S. C. Mills, J. Am. Oil. Chem. Soc., 48: 358. 1971.

101) Ackerson, B. A., R. R. Johnson and R. L. HenDRICKSON, J. Nutr., 106: 1383. 1976.

102) Plowman, R. D., J. Bitman, C. H. Gukdon, L. P. Dryden, H. K. Goering and T. R. Wrenn, J. Dairy Sci., 55: 204. 1972.

103) Storry I. E., P. E. Brumby, A. J. Hall and V, W. Johnson, J. Dairy Res,, 41: 165. 1974.

104) MacLeod, G. K., Y. Yu and L. R. Schaeffer, J. Dairy Sci., 60: 726. 1977.

105) Bitman, J., T.R. Wrenn, D. L. Wood, G. C. Mustakas, E. C. Baker and W, J. Wolf, J, Am. Oil. Chem. Soc., 52: 415. 1975.

106) PAN, Y.S., L. J. Cook and T. N. Scott, J. Dairy Res., 39: 203. 1972.

107) Cook, L. J., T.W. ScotT and Y.S. PAN, J. Dairy Res., 39: 211. 1972.

108) Scott, T.W., L. J. Cook, K. A. Ferguson, I. W. McDonald, R. A. Buchanan and G. LoftusHills, Aust. J. Sci., 32: 291. 1970.

109) Goering, H. K., T. R. Wrenn, L.F. Edmondson, J.R. Weyant, D. L. Wood and J. Bitman, J. Dairy Sci., 60: 739. 1977.

110) Mattos, W., and D. L. Palmquist, J. Dairy Sci., 57: 1050. 1974. 